\title{
CONCURRENT TRAINING AND TAURINE IMPROVE LIPID PROFILE IN POSTMENOPAUSAL WOMEN
}

\author{
TREINAMENTO CONCORRENTEE TAURINA MELHORAM PERFIL LIPÍDICO EM MULHERES PÓS MENOPAUSA
}

ENTRENAMIENTO CONCURRIDO JUNTO CON TAURINA MEJORA PERFIL LIPIDICOEN MUJERES

ARTIGO ORIGLL

Artigo OrIGINAL

POSMENOPÁUSICAS

Camila Buonani
(Physical Education Professional) $^{1}$
Fabrício Eduardo Rossi ${ }^{2}$
(Physical Education Professional)
Tiego Aparecido Diniz
(Physical Education Professional)
Ana Claúdia Fortaleza ${ }^{4}$
(Physiotherapist)
Juliana Viezel
(Physical Education Professional) $^{1}$
Malena Ricci Picolo
(Nutritionist)
Rômulo A. Fernandes
(Physical Education Professional)
Ismael Forte Freitas Júnior ${ }^{1}$
(Physical Education Professional)

1. Post-Graduate Program in Movement Sciences, Department of Physical Education, Universidade Estadual Paulista (UNESP),

Presidente Prudente, São Paulo, SP, Brazil.

2.Universidade Federal do Piauí (UFPI), Department of Physical

Education, Immunometabolism of the skeletal muscle and of the exercise research group, Teresina, PI, Brazil.

3. Department of Cell and

Developmental Biology, Instituto de Ciências Biomédicas, Universidade de São Paulo (USP), São Paulo, SP, Brazil.

4. Universidade do Oeste Paulista (UNOESTE), Presidente Prudente, São Paulo, Brazil.

5. Post-Graduate Program in Physiotherapy, Universidade Estadual Paulista (UNESP),

Presidente Prudente, São Paulo, SP, Brazil.

\section{Correspondence}

Camila Buonani

Department of Physical Education, Universidade Estadual Paulista (UNESP). Rua Roberto Simonsen, 305, Centro Educacional, Presidente Prudente, SP, Brazil. 19060-900. camila.buonani@unesp.br

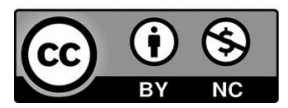

\begin{abstract}
Introduction: Taurine plays an important role in metabolism and can positively influence body composition, since it is believed that in appropriate concentrations this amino acid (AA) can reduce perceived exertion, thereby delaying the onset of fatigue; however, the effect of this AA combined with concurrent training in postmenopausal women is unknown. Objective: To analyze the effects of concurrent training (aerobic+resistance) and taurine supplementation on the metabolic profile of postmenopausal women. Methods: Forty-three postmenopausal women were randomly divided into the following groups: Control ( $C[N=13]$ ), Taurine ( $T[N=8]$ ), Taurine+Exercise (TE [N=13]), and Placebo+Exercise ( $[\mathrm{N}=9])$. The supplemented groups received capsules corresponding to a daily taurine intake of $1.5 \mathrm{~g}$. Concurrent training (CT) took place three times a week and consisted of 50 minutes of resistance training and 30 minutes of aerobic training. Body composition was assessed using DXA, in addition to biochemical profile analysis: triglycerides, total cholesterol, low-density lipoprotein cholesterol and high-density lipoprotein cholesterol. The intervention period lasted for eight weeks. Statistical significance was set at $5 \%$. Results: The TE group presented a statistical reduction in terms of relative change in the percentage of total body fat (\%) $(-4.1 \pm 3.0)$ and trunk fat $(\%)(-4.4 \pm 3.9)$, with greater lean body mass $(\mathrm{kg})$ gain $(3.9 \pm 2.5)$ when compared to groups $C$ $(0.3 \pm 3.7, p=0.005 ; 0.8 \pm 4.3, p=0.024 ;-1.1 \pm 3.1, p<0.001 ;$ respectively) and $(1.2 \pm 3.4, p=0.004 ; 1.6 \pm 5.4, p=0.023 ;-1.2 \pm 2.9$; $\mathrm{p}=0.002$; respectively). The TE group presented a greater percentage reduction of total cholesterol $(-5.8 \pm 7.1 \mathrm{mg} / \mathrm{dl})$ when compared to group T $(11.5 \pm 19.1 \mathrm{mg} / \mathrm{dl})$ ). The TE group presented a significant decrease in LDL-c $(-13.6 \pm 9.2$ $\mathrm{mg} / \mathrm{dl})$ compared to groups $C(3.5 \pm 13.9 \mathrm{mg} / \mathrm{dl}, \mathrm{p}=0.014)$ and $\mathrm{T}(9.9 \pm 24.3 \mathrm{mg} / \mathrm{dl}, \mathrm{p}=0.027)$. Conclusion: The combination of concurrent training and taurine supplementation promoted a reduction in total cholesterol and LDL-C levels in postmenopausal women. Level of Evidence l; Study type: Randomized clinical study.
\end{abstract}

Keywords: Body composition; Resistance training; Metabolism.

\section{RESUMO}

Introdução: A taurina desempenha um papel importanteno metabolismo e pode influenciar positivamente a composição corporal, uma vez que, na concentração apropriada, este aminoácido pode diminuir a percepção de esforço e retardar o aparecimento da fadiga; entretanto, o efeito desse aminoácido combinado com o treinamento concorrente (TC) édesconhecido em mulheres pós-menopausa. Objetivo: Analisar os efeitos do TC (aeróbico+resistência) e da suplementação com taurina nesse perfil metabólico de mulheres pós menopausa. Métodos: Foram avaliadas 43 mulheres pós-menopausa que foram divididas randomicamente nos seguintes grupos: Controle ( $C[N=13])$, Taurina (T [N=8]), Taurina+Exercício (TE $[N=13])$ e Placebo+Exercício (E $[N=9]$ ). Os grupos suplementados com taurina receberam cápsulas e consumiram 1,5 gramas/dia dessa substância. O TC aconteceu três vezes por semana (50 minutos de treinamento resistido e 30 minutos de treinamento aeróbico). A avaliação da composição corporal foi realizada por meio do DXA; além disso, foram analisados o perfil bioquímico com dosagem de triglicérides, colesterol total (CT), colesterol de lipoproteína de baixa densidade ( $L D L-c)$ e colesterol de lipoproteína de alta densidade (HDL-C). A intervenção teve duração de oito semanas. Resultados: O grupo TE apresentou redução percentual significativa da gordura corporal total $(-4,1 \pm$ $3,0)$ e gordura de tronco $(-4,4 \pm 3,9)$ e maiores ganhos da massa corporal magra $(3,9 \pm 2,5)$ em comparação ao grupo $C(0,3 \pm 3,7, p=0,005 ; 0,8 \pm 4,3, p=0,024 ;-1,1 \pm 3,1, p<0,001$; respectivamente) e ao grupo $T(1,2 \pm 3,4, p=0,004 ; 1,6 \pm$ $5,4, p=0,023 ;-1,2 \pm 2,9 ; p=0,002 ;$ respectivamente). O grupo TE apresentou maiores reduções do CT (-5,8 $\pm 7,1 \mathrm{mg} / \mathrm{dl})$ em comparação ao grupo $T(11,5 \pm 19,1 \mathrm{mg} / \mathrm{d})$. O grupo TE apresentou significativa redução do LDL-c (-13,6 $\pm 9,2 \mathrm{mg} / \mathrm{d})$ em comparação ao grupo C $(3,5 \pm 13,9 \mathrm{mg} / \mathrm{dl}, p=0,014)$ e ao grupo $T(9,9 \pm 24,3 \mathrm{mg} / \mathrm{dl}, p=0,027)$. Conclusão: A associação TC esuplementação com taurina promoveu redução dos níveis de colesterol total e LDL-cem mulheres pós-menopausa. Nível de Evidência l; Tipo de Estudo: Estudo clínico randomizado.

Descritores: Composição corporal; Treinamento de resistência; Metabolismo.

\section{RESUMEN}

Introducción: La taurina desempeña un papel importante en el metabolismo y puede influenciar positivamente la composición corporal, ya que en la concentración apropiada este aminoácido puede disminuir la percepción de esfuerzo y retrasar la aparición de la fatiga; sin embargo, el efecto de este aminoácido combinado con el entrenamiento 
concurrente (EC) es desconocido en mujeres posmenopáusicas. Objetivo: Analizar los efectos del EC (aeróbicotresistencia) y de la suplementación con taurina en este perfil metabólico de mujeres posmenopáusicas. Métodos: Se evaluaron 43 mujeres posmenopáusicas que se dividieron aleatoriamente en los siguientes grupos: Control ( $C$ [ $N=13]$ ), Taurina $(T[N=8]$ ), Taurina+Ejercicio (TE $[N=13])$, Placebo+Ejercicio $(E[N=9])$. Los grupos suplementados con taurina recibieron 1,5 gramos/día de esta sustancia. El EC ocurrió tres veces por semana (50 minutos de entrenamiento resistido y 30 minutos de entrenamiento aeróbico). La composición corporal fue realizada por medio del DXA; además, se analizaron el perfil bioquímico con dosificaciones de triglicéridos, colesterol total (CT), colesterol de lipoproteína de baja densidad (LDL-c) y colesterol de lipoproteína de alta densidad (HDL-c). La intervención tuvo duración de ocho semanas. Resultados: El grupo TE presentó reducción porcentual significativa de la grasa corporal total $(-4,1 \pm 3,0)$ y grasa del tronco $(-4,4 \pm 3,9)$ y mayores ganancias de masa corporal magra $(3,9 \pm 2,5)$ en comparación al Grupo $C(0,3 \pm 3,7, p=0,005,0,8 \pm 4,3, p=0,024,-1,1 \pm 3,1, p<0,001$, respectivamente) y al Grupo $T(1,2 \pm 3,4, p=0,004$; $, 6 \pm 5,4, p=0,023 ;-1,2 \pm 2,9 ; p=0,002 ;$ respectivamente). El Grupo TE presentó mayores reducciones del CT (-5,8 $\pm 7,1 \mathrm{mg} / \mathrm{dl}$ ) en comparación con el Grupo T (11,5 19,1 mg/dl). El Grupo TE presentó una significativa reducción del LDL-C (-13,6 \pm 9,2 mg/dl) en comparación con el Grupo C (3,5 $\pm 13,9 \mathrm{mg} / \mathrm{dl}, p=0,014)$ y el Grupo T (9,9 $\pm 24,3 \mathrm{mg} / \mathrm{dl}$, $p=0,027)$. Conclusión: La asociación de ECy suplementación con taurina promovió reducción de los niveles de colesterol total y LDL-cen mujeres posmenopáusicas. Nivel de evidencia l; Tipo de Estudio: Estudio clínico aleatorizado.

Descriptores: Composición corporal; Entrenamiento de resistencia; Metabolismo.

\section{INTRODUCTION}

Menopause is characterized by reduced estrogen production and the interruption of the menstrual cycle, resulting in the end of ovarian function, and is recognized retrospectively after a year of amenorrhea. ${ }^{1}$ In addition to the impact on the reproductive system, menopause may also be responsible for significant changes in body composition, since, after this event, many women experience weight gain and adiposity, particularly in their core ${ }^{2}$ and, thus, are more likely to develop an atherogenic lipid profile and heart disease. ${ }^{3}$

Concurrent training (aerobic + resistance) can minimize the effects of aging on body composition and the metabolism. This stems from an increase in lean mass and a reduction in body fat, ${ }^{4}$ in addition to increasing insulin sensitivity and energy expenditure, both during and after exercise, ${ }^{5}$ improving lipid metabolism. ${ }^{6}$

Some supplements such as amino acids (AA), have been used as additional strategies to enhance the results in health and quality of life from exercise programs. Among these AAs, is taurine (2-aminoethanesulfonic acid) which, in humans, is synthesized in the liver and considered a semi-essential AA. The quantity produced by the organism is low and it is therefore recommended that this be supplemented through diet, such as meat and seafood. ${ }^{7}$

Studies have suggested that taurine plays an important role in metabolism ${ }^{8}$ and can positively influence body composition, since it is believed that in appropriate concentrations this AA can decrease perceived exertion, and thus, delay the onset of fatigue, ${ }^{9}$ presumably causing an individual to tolerate higher exercise intensity and volume, resulting in higher gains. However, no studies were found in the literature which investigated the effects of the combination of taurine supplementation and concurrent training on the body composition and lipid profile of postmenopausal women.

The hypothesis of this study was that supplementation with taurine, associated with concurrent training, would promote gains in lean body mass, reduce overall body and trunk fat, and improve the lipid profile of postmenopausal women. Thus, the aim of the present study was to analyze the effects of concurrent training and supplementation with taurine on the body composition and lipid profile of postmenopausal women.

\section{METHODS}

\section{Study Design}

This double-blinded controlled study was carried out from January of 2012 to August of 2014 at the Science and Technology Department of the Paulista State University, Brazil. Evaluations were performed at baseline and again after eight weeks of training and involved: screening for inclusion in the study; anthropometric, body composition and lipid profile measurements and three nonconsecutive 24-hour dietary recalls which were conducted at two periods: one week before the beginning of the intervention and in the first week after the intervention.

\section{Subjects}

For the sample size calculation the average of the triacylglycerol variable obtained from the study of Balducci, Zanuso ${ }^{10}$ was considered, together with the standard deviation from that study $(23.9 \mathrm{mg} / \mathrm{dL})$. Adopting a power of $80 \%$ for a two-tailed test and a maximum desired error of 5\%, the equation indicating the need for at least six individuals per group. Predicting possible sample losses, each group started the protocol with 12 participants.

The invitation to participate in the study was made through dissemination on the radio, television and in local newspapers. To participate in this study, the following inclusion criteria were adopted: 1) to be in menopause [no menstrual cycle for at least a year and serum levels of the follicle stimulating hormone $\left.(\mathrm{FSH}) \geq 30 \mathrm{UI} / \mathrm{l}_{; 1}^{11} 2\right)$ to be between the ages of 50 and 79 on the date of the evaluation; 3) not to present any physical limitations or health problems which would hinder the performance of the evaluations; 4) to possess a medical certificate to participate in the training program; 5) to perform all evaluations; 6) to sign the informed consent form for participation in the study (protocol 64/2011). The study was approved by the Ethics Research Group of the Sao Paulo State University Campus Presidente Prudente (Protocol 64/2011).

The following exclusion criteria were adopted: accumulating three consecutive absences or four non-consecutive absences during one month.

After the dissemination, 141 postmenopausal women signed up to participate in the study, of which 64 met the inclusion/exclusion criteria and agreed to participate in the intervention. The participants were divided randomly into the following groups: Control $(C[n=16])$; Taurine $(T[n=16])$, Taurine + Exercise (TE $[n=16])$ Placebo + Exercise ( $E[n=16])$. The final sample consisted of 43 women, the reasons for dropping out were: lack of time, difficulties related to locomotion to the university, and personal problems. The flow, drop-out and final sample of the study was presented in the Figure 1. 


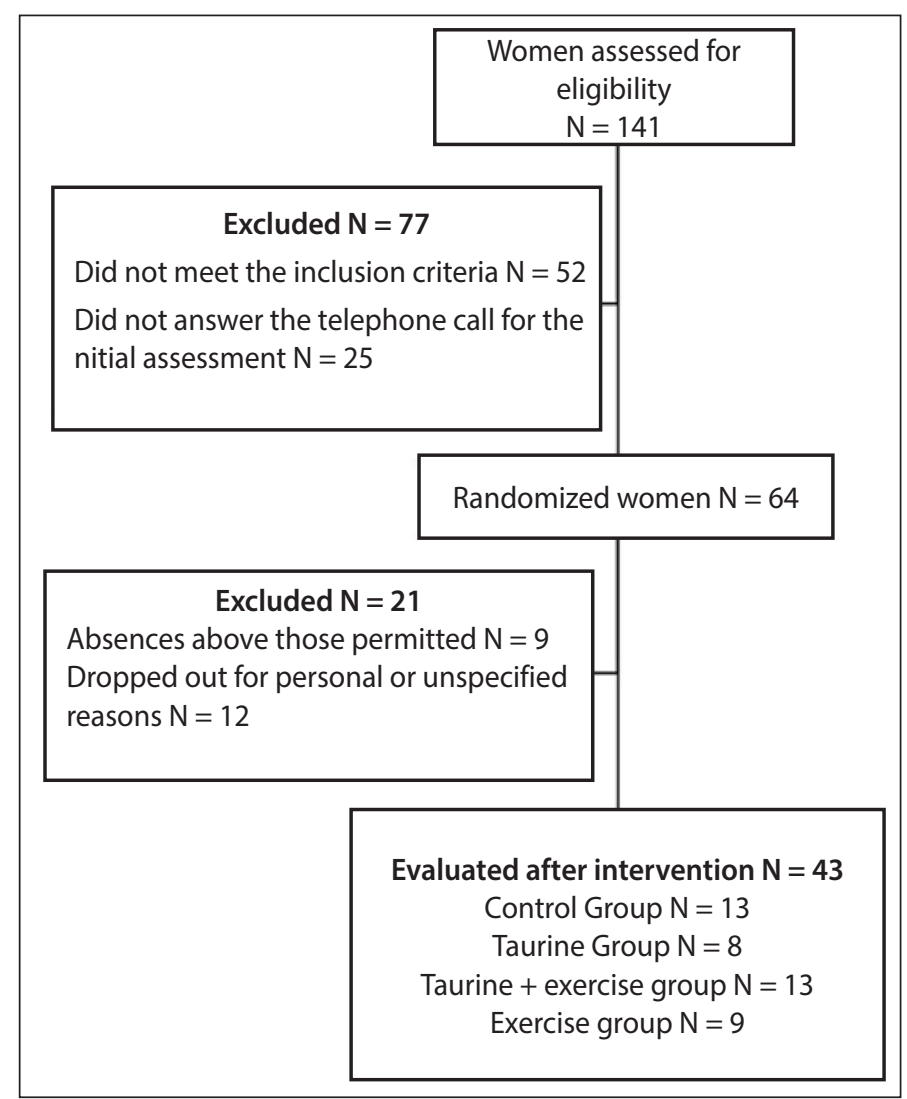

Figure 1. Flow of participants during the study.

\section{Procedures}

\section{Anthropometry and Body Composition}

Body weight was measured using an electronic Filizola-brand scale. Height was measured using a Sanny-brand fixed stadiometer. The values of height and weight were used to calculate body mass index (BMI) [weight (kg)/height (m) ${ }^{2}$.

For analysis of body composition a Dual Energy X-ray absorptiometry (DXA [General Electric Medical Systems, Lunar DPX MD, Madison, WI, USA]) device brand was used with software version 4.7. The following body composition variables were evaluated: total mass; lean body mass; total body and trunk fat, expressed in absolute and relative values.

To calculate the technical error of measurement of the DXA, two whole body evaluations were performed, by the same evaluator, on two consecutive days with 12 female subjects. From the results obtained the error was estimated as follows: $1.48 \%$ for total body fat; $1.38 \%$ for trunk fat; $2.06 \%$ for total lean body mass. The test re-test intraclass correlation coefficient of these procedure has been shown reliable (ICC between 0.91 to 0.99 for the variables used in this study).

\section{Blood Samples}

After an overnight fast (12 h), venous blood samples were collected to measure FSH, triglycerides (TG), fasting total cholesterol (TC), high-density lipoprotein cholesterol (HDL-c) and low-density lipoprotein cholesterol (LDL-c), using the colorimetric technique in dry chemical and Johnson and Johnson equipment, model Vitros 250.

\section{Aerobic Training Procedures}

The determination of the intensity of the aerobic training was performed using the critical velocity protocol proposed by Wakayoshi, Yoshida. ${ }^{12}$ The studied group traveled three distances (400,800 and $1200 \mathrm{~m}$ ) on a running track on separate, nonconsecutive days. The participants were instructed to cover the distance in the shortest possible time, which was recorded using a digital stopwatch (Polar $\left.{ }^{\circledR}\right)$. After four weeks the procedures were repeated to adjust the intensities.

\section{Resistance training procedures}

The exercises used in the program were: $45^{\circ}$ leg press, leg extension, leg curl, bench press, seated row, arm curl, triceps extension, side elevation with dumbbells and abdominal exercises. The training load was adjusted every four training weeks in order to maintain the prescribed number of repetitions: phases [phase 1 (1st to 4th week, 15 repetitions at $\sim 65 \%$ of maximum, three sets per exercise, $60-90$ sec between sets); phase 2 (5th to 8th week, 12 repetitions at $\sim 70 \%$ of maximum, three sets per exercise, $60-90 \mathrm{sec}$ between sets); phase 3 (9th to 12 th week, 10 repetitions at $\sim 75 \%$ of maximum, three to four sets per exercise, 60-90 sec between sets) and phase 4 (13th to 16th week, eight repetitions at $\sim 80 \%$ of maximum, three to four sets per exercise, 60-90 sec between sets)].

The intensity of the resistance training was controlled through the zone of maximum repetitions. The series were executed until momentary exhaustion, if the participants performed more than the maximum predicted, the load was increased in order to respect the training zone. ${ }^{13}$ The test of one maximum repetition (1RM) was performed only for the Leg press and bench press, and consisted of a warm-up, followed by the performance of one series of ten repetitions of each exercise without overload. The load was gradually increased during the test until the participants were no longer able to perform the entire movement, and three attempts were allowed to meet the corresponding 1RM load. For recovery, an interval of three to five minutes between attempts was given. After four weeks the procedures were repeated to adjust the intensities.

\section{Concurrent Training Protocol}

The women who underwent the concurrent training performed the protocol three times a week on nonconsecutive days for eight weeks. Initially, the participants had a period of two weeks of familiarization. Only after familiarization, were the tests for determining training load performed. The concurrent training program lasted for 80 minutes per session, with 50 minutes of resistance training and 30 minutes of aerobic training.

To ensure that the intensities as well as the training routine were appropriate, all activities were accompanied by both previously trained monitors and the researchers responsible for the project. At the beginning of each training session blood pressure was monitored and at the end 10 minutes of stretching were conducted to cool down.

\section{Supplementation Protocol}

Twenty-four hour dietary recalls were conducted on three nonconsecutive days (one weekend and two weekdays). ${ }^{14}$ The participants were oriented by a nutritionist. Data was analyzed by the same nutritionist using the software NutWin, version 1.5 (Programa de Apoio à Nutrição, Universidade Federal de São Paulo, Brazil, 2002).

The T and TE groups consumed orally $1.5 \mathrm{~g}$ of taurine/day, the $E$ and C group received capsules containing potato starch. The participants received three daily doses of taurine, $500 \mathrm{mg}$ on waking, $500 \mathrm{mg}$ at lunchtime and $500 \mathrm{mg}$ in the evening.

\section{Statistical Analysis}

Initially, Levene's test identified that there was a homogeneity of variance for all numerical variables, except relative changes for HDL-C. Thus, HDL-C values were log-transformed. The descriptive statistic was composed of mean and standard-deviation.

The comparisons of the initial and final values of the dietary recalls of the groups were performed using the Wilcoxon test due to non-parametric distribution even after log-transformation (therefore, presented as median and inter-quartile range). Relative variations 
were calculated, taking into account the values obtained at the initial and final moments of the study ([Final Moment - Baseline moment] / Baseline moment * 100). Comparisons of relative values among the experimental groups were performed by analysis of variance and Tukey's post hoc test was applied when necessary. All analyses were performed using the SPSS program, version 17.0 (SP.SS Inc, Chicago, IL) and statistical significance was set at $<5 \%$.

\section{RESULTS}

The study consisted of 43 postmenopausal women (FSH $=69.4 \pm$ 26.2), aged between 50.7 and 77 years $(60.5 \pm 6.5)$ years. The values in Table 1 and 2 refer to the initial values and comparisons between the groups of body composition and biochemical profile, of the study participants. When comparing the values obtained in the dietary recalls no significant differences were found in any of the groups studied (Table 3).

Figure 2 refers to the percentage changes in body composition which showed a significant difference between the pre- and post-intervention periods.

It was observed that the TE group presented significant reductions in the percentage of total body fat ( $p=0.005, p=0.004)$ and trunk fat $(p=0.024, p=0.023)$, and higher improvement in the lean mass $(p<0.000$, $p=0.002$ ), when compared to $C$ and T groups, respectively. The E group showed significant increase in the lean mass ( $p=0.001, p=0.004)$ and reduction in the percentage of trunk fat ( $p=0.042, p=0.035)$, when compared to $C$ and $T$ groups, respectively. The $E$ group also presented higher total body mass $(p=0.011)$, when compared to $C$ group.

Figure 3 shows the percentage values of the changes in the TC and LDL-C.

After the analysis of relative changes in $\mathrm{TC}$, higher reductions in the TE group, when compared to the $T(p=0.020)$ group were observed. In relation to $L D L-C$, the group which trained and took taurine presented higher reductions, when compared to the $C(p=0.014)$ and $T$ $(p=0.027)$ groups.

Table 1. General characteristics of body composition and comparison between the groups at the beginning of the intervention, expressed as mean and standard deviation.

\begin{tabular}{|c|c|c|c|c|c|}
\hline Groups & $\begin{array}{l}\text { Control } \\
\mathrm{N}=13\end{array}$ & $\begin{array}{c}\text { Taurine } \\
\mathrm{N}=8\end{array}$ & $\begin{array}{c}\text { Taurine }+ \\
\text { Exercise } \\
\mathrm{N}=13\end{array}$ & $\begin{array}{c}\text { Exercise } \\
\mathrm{N}=9\end{array}$ & $\mathrm{p}$ \\
\hline Age (years) & $63.3 \pm 6.6$ & $58,6 \pm 8.1$ & $59.1 \pm 5.3$ & $59.7 \pm 6.0$ & 0.220 \\
\hline Body mass $(\mathrm{kg})$ & $62.8 \pm 13.9$ & $64.7 \pm 8.9$ & $63.3 \pm 7.8$ & $59.2 \pm 10.1$ & 0.739 \\
\hline $\mathrm{BMI}\left(\mathrm{kg} / \mathrm{m}^{2}\right)$ & $26.4 \pm 5.0$ & $26.0 \pm 3.3$ & $24.4 \pm 2.5$ & $24.5 \pm 3.2$ & 0.436 \\
\hline Lean mass (kg) & $34.1 \pm 7.0$ & $34.5 \pm 3.1$ & $34.3 \pm 4.7$ & $32.1 \pm 3.8$ & 0.718 \\
\hline Body fat (\%) & $41.7 \pm 5.3$ & $43.0 \pm 4.8$ & $41.8 \pm 5.5$ & $41.7 \pm 4.5$ & 0.942 \\
\hline Body fat (kg) & $26.5 \pm 7.8$ & $28.1 \pm 6.6$ & $26.6 \pm 5.5$ & $25.1 \pm 6.5$ & 0.821 \\
\hline Trunk fat (\%) & $44.6 \pm 5.4$ & $46.7 \pm 4.9$ & $44.8 \pm 5.8$ & $45.4 \pm 5.4$ & 0.844 \\
\hline Trunk fat (kg) & $14.0 \pm 3.9$ & $15.0 \pm 3.6$ & $13.6 \pm 3.1$ & $13.3 \pm 3.4$ & 0.779 \\
\hline
\end{tabular}

Table 2. Biochemical profile and comparison between the groups at the beginning of the intervention, expressed as mean and standard deviation.

\begin{tabular}{|c|c|c|c|c|c|}
\hline & $\begin{array}{l}\text { Control } \\
N=13\end{array}$ & $\begin{array}{c}\text { Taurine } \\
\mathrm{N}=8\end{array}$ & $\begin{array}{c}\text { Taurine }+ \\
\text { Exercise } \\
\mathrm{N}=13\end{array}$ & $\begin{array}{c}\text { Exercise } \\
\mathrm{N}=9\end{array}$ & $p$ \\
\hline $\mathrm{TG}(\mathrm{mg} / \mathrm{dL})$ & $145.9 \pm 56.0$ & $98.3 \pm 57.8$ & $117.6 \pm 58.4$ & $120.1 \pm 75.2$ & 0.375 \\
\hline $\mathrm{TC}(\mathrm{mg} / \mathrm{dL})$ & $200.5 \pm 34.1$ & $179.8 \pm 26.2$ & $207.4 \pm 36.3$ & $194.8 \pm 38.0$ & 0.354 \\
\hline $\mathrm{HDL}-\mathrm{c}(\mathrm{mg} / \mathrm{dL})$ & $50.3 \pm 8.2$ & $56.4 \pm 10.5$ & $55.2 \pm 10.9$ & $58.4 \pm 19.4$ & 0.468 \\
\hline $\mathrm{LDL}-\mathrm{c}(\mathrm{mg} / \mathrm{dL})$ & $121 \pm 26.1$ & $104.8 \pm 20.3$ & $128.6 \pm 32.8$ & $112.8 \pm 20.3$ & 0.212 \\
\hline FSH $(\mathrm{mUl} / \mathrm{ml})$ & $70.7 \pm 17.8$ & $65.7 \pm 23.5$ & $67.9 \pm 22.1$ & $72.7 \pm 37.6$ & 0.957 \\
\hline
\end{tabular}

Table 3. Total energy consumption and macronutrients, expressed as median and interquartile range.

\begin{tabular}{|c|c|c|c|c|c|}
\hline & & $\begin{array}{l}\text { Energy } \\
\text { (Kcal) }\end{array}$ & $\begin{array}{c}\text { Carbohydrate } \\
\text { (g) }\end{array}$ & $\begin{array}{l}\text { Protein } \\
\text { (g) }\end{array}$ & $\begin{array}{l}\text { Fat } \\
\text { (g) }\end{array}$ \\
\hline \multirow{3}{*}{ Control } & Pre & $\begin{array}{c}1513.0 \\
(1079.3-2233.8) \\
\end{array}$ & $\begin{array}{c}212.2 \\
(133.7-295.7)\end{array}$ & $\begin{array}{c}65.3 \\
(33.2-95.4)\end{array}$ & $\begin{array}{c}42.8 \\
(28.3-99.3) \\
\end{array}$ \\
\hline & Post & $\begin{array}{c}1621.0 \\
(1051.4-1933.3) \\
\end{array}$ & $\begin{array}{c}213.2 \\
(136.8-259.8) \\
\end{array}$ & $\begin{array}{c}65.5 \\
(49.6-105.1) \\
\end{array}$ & $\begin{array}{c}52.4 \\
(36.5-91.0) \\
\end{array}$ \\
\hline & $p$ & 0.507 & 0.753 & 0.382 & 0.507 \\
\hline \multirow{3}{*}{ Taurine } & Pre & $\begin{array}{c}2050.5 \\
(1415.7-2549.5) \\
\end{array}$ & $\begin{array}{c}246.0 \\
(110.9-259.5) \\
\end{array}$ & $\begin{array}{c}100.5 \\
(40.5-117.2) \\
\end{array}$ & $\begin{array}{c}79.0 \\
(29.6-123.8) \\
\end{array}$ \\
\hline & Post & $\begin{array}{c}1997.5 \\
(1523.5-2730.7) \\
\end{array}$ & $\begin{array}{c}249.0 \\
(117.9-296.2) \\
\end{array}$ & $\begin{array}{c}105.5 \\
(45.8-112.3) \\
\end{array}$ & $\begin{array}{c}79.5 \\
(32.3-132.8) \\
\end{array}$ \\
\hline & $p$ & 0.173 & 0.249 & 0.225 & 0.138 \\
\hline \multirow{3}{*}{$\begin{array}{c}\text { Taurine + } \\
\text { Exercise }\end{array}$} & Pre & $\begin{array}{c}1750.0 \\
(1022.1-2427.3) \\
\end{array}$ & $\begin{array}{c}203.3 \\
(121.8-356.6) \\
\end{array}$ & $\begin{array}{c}84.0 \\
(51.6-113.2) \\
\end{array}$ & $\begin{array}{c}58.0 \\
(33.4-100.0) \\
\end{array}$ \\
\hline & Post & $\begin{array}{c}1669.5 \\
(1207.2-2394.3)\end{array}$ & $\begin{array}{c}189.4 \\
(156.1-322.5)\end{array}$ & $\begin{array}{c}81.4 \\
(65.6-119.1)\end{array}$ & $\begin{array}{c}61.9 \\
(34.4-95.2) \\
\end{array}$ \\
\hline & $p$ & 0.583 & 0.209 & 0.937 & 0.346 \\
\hline \multirow{3}{*}{ Exercise } & Pre & $\begin{array}{c}1718.5 \\
(1341.3-2315.2) \\
\end{array}$ & $\begin{array}{c}231.7 \\
(185.6-293.5) \\
\end{array}$ & $\begin{array}{c}72.3 \\
(45.3-115.6) \\
\end{array}$ & $\begin{array}{c}68.2 \\
(45.3-185.6) \\
\end{array}$ \\
\hline & Post & $\begin{array}{c}1568.5 \\
(1412.3-2227.1)\end{array}$ & $\begin{array}{c}241.6 \\
(193.6-289.3)\end{array}$ & $\begin{array}{c}75.7 \\
(49.1-117.2)\end{array}$ & $\begin{array}{c}54.5 \\
(39.5-85.8) \\
\end{array}$ \\
\hline & $p$ & 0.285 & 0.721 & 0.959 & 0.139 \\
\hline
\end{tabular}

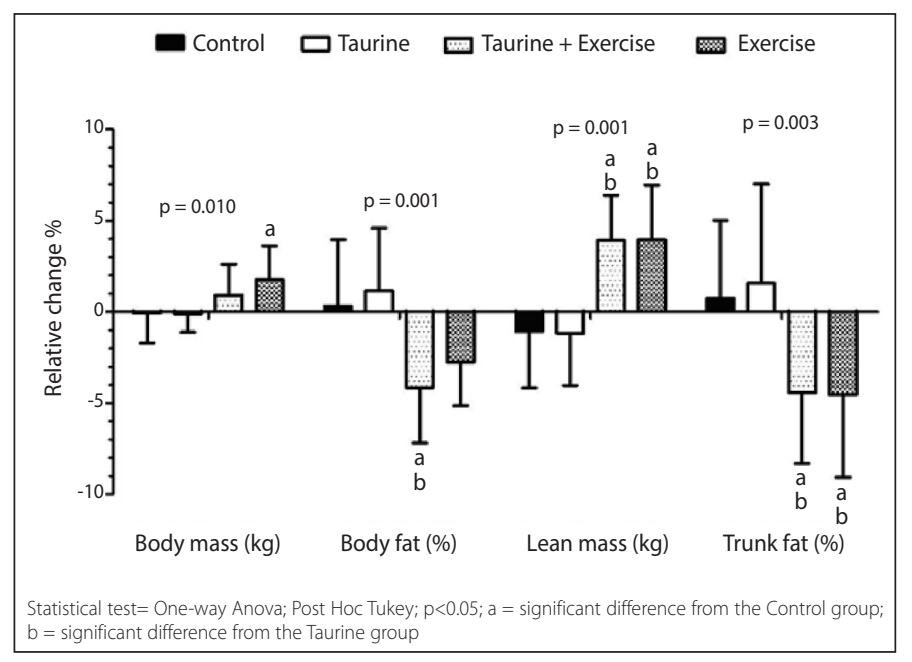

Figure 2. Mean percentage changes in total body composition after eight weeks of intervention, expressed as mean and standard deviation.

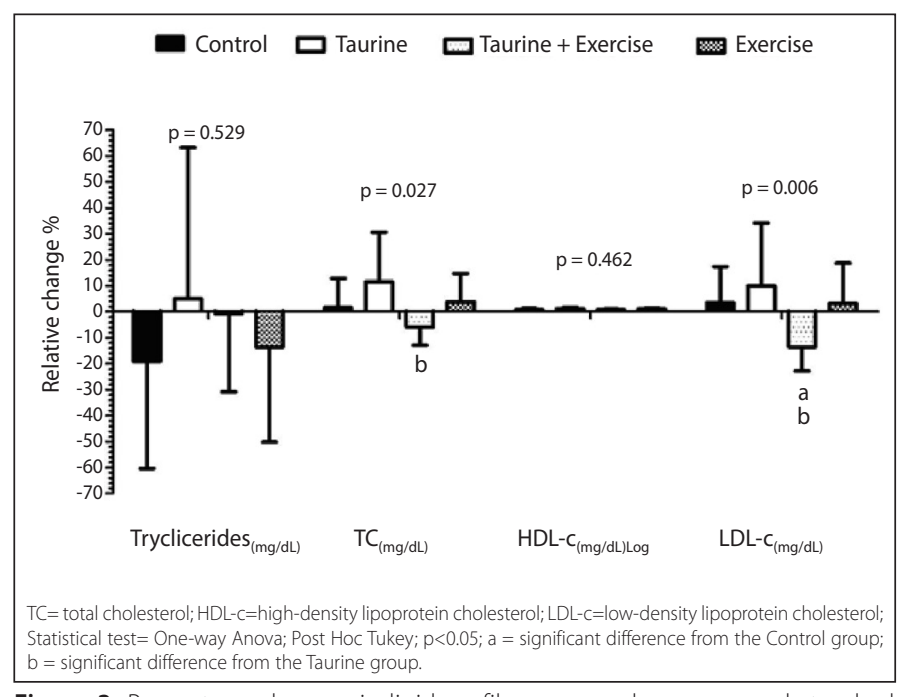

Figure 3. Percentage changes in lipid profile, expressed as mean and standard deviation. 


\section{DISCUSSION}

Among the principal findings of this study, it is worth highlighting that, after eight weeks of supplementation with taurine alone and associated with concurrent training, there was a reduction in total and core body fat and an increase in lean mass in both the groups which received training. Regarding the lipid profile, there was a statistically significant reduction in total cholesterol and LDL-c only in the TE group.

Rutherford, Spriet, ${ }^{15}$ verified the acute effect of supplementation of 1.66 grams of taurine in cyclists, and found increased fat oxidation after supplementation, suggesting that taurine may act on body composition, helping to reduce body fat. It has been suggested that taurine increases skeletal and cardiac muscle contraction, as it participates in the regulation of intracellular calcium and enhances the availability of calcium for contraction. ${ }^{16}$

Beyranvand, Khalafi, ${ }^{17}$ observed that individuals with heart failure who took 0.5 grams of taurine, three times a day for two weeks, showed improved performance in the treadmill test, with increased exercise time and distance traveled when compared to the placebo group. These findings corroborate the study of Alford, Cox ${ }_{1}^{18}$ in which they used an energy drink containing taurine on trained individuals and observed a 9\% increase in aerobic resistance.

The groups that underwent concurrent training (TE and E) presented a statistically significant reduction in body fat percentage, percentage of upper-body fat and an increase in lean body mass (Figure 2), when compared to the groups which did not train. Therefore, the results of this study indicate that isolated supplementation of 1.5 grams/day of taurine for eight weeks does not appear to influence body composition, even when associated with concurrent training, in postmenopausal women.

These findings corroborate with the results obtained by Lixandrão, Bonganha, ${ }^{19}$ who found that concurrent training for 16 weeks of intervention, performed by postmenopausal women, promoted increased muscle mass and strength. In a study conducted by Rossato, Binotto $^{20}$ with perimenopausal women, it was found that after 20 weeks of concurrent training there was no reduction in body fat or increase in lean mass, unlike our findings. It is worth mentioning that the changes in body composition in the present study were obtained in just eight weeks.

After menopause there is an increase in the concentration of plasma lipids, a fact which contributes to an increased incidence of cardiovascular events in women. ${ }^{21}$ Changes in the lipid metabolism appear to be related to decreased amounts of the hormone estradiol, and this condition is accompanied by increased levels of triglycerides, total cholesterol, LDL-c and reduced levels of $\mathrm{HDL}-{ }^{22}{ }^{22}$ Given that abnormal values of TC; especially increased LDL-c and decreased HDL-c are important risk factors for the occurrence of circulatory and cardiac system diseases.

Research regarding taurine has been widely performed in animal models, aimed at better understanding the effect of this AA on the lipid metabolism. From these studies it is evident that supplementation with taurine can reduce plasma and liver cholesterol concentrations, especially the very low density lipoprotein and LDL-c in situations of diet-induced hypercholesterolemia, as well as increasing levels of $\mathrm{HDL}-\mathrm{c}^{23}$

It is believed that taurine increases the activity of CYP7A1, ${ }^{23}$ the enzyme which stimulates the synthesis of bile acids, considered the main regulatory pathway for cholesterol homeostasis in the body. ${ }^{24}$ Therefore, if there is an increase in the quantity of bile acids, consequently, a greater amount of cholesterol is withdrawn from circulation. Additionally, it is believed that taurine acts on the LDLR protein responsible for clearance of about two thirds of LDL-c from circulation, ${ }^{25}$ therefore, it is extremely important to maintain the balance of this lipoprotein in the body.

Based on the literature, supplementation with taurine seems to be interesting in aiding the treatment of individuals diagnosed with some type of metabolic disorders such as diabetes or arterial hypertension. This AA, besides acting directly on the lipid metabolism, also displays a potential antioxidant and anti-inflammatory role, and promotes improvement of the endothelial function by stimulating the increase of nitric oxide, contributing to the metabolic profile of individuals with heart disease. ${ }^{26}$

The results here suggest that the association of concurrent training with taurine supplementation appears to be beneficial for reducing TC and LDL-C. In a study performed by Shaw, Shaw, ${ }^{27}$ sedentary adults were submitted to 16 weeks of concurrent training and aerobic training in isolation where it was observed that both interventions reduced TC and increased HDL-c. Seo, So ${ }^{28}$ analyzed the effects of 12 weeks of concurrent training on middle aged women and found a significant increase in $\mathrm{HDL}-\mathrm{c}$ and a reduction in TG and body fat percentage.

It is known that diet is an important source for obtaining exogenous taurine, which is principally found in seafood, dark avian meat ${ }^{7}$ and in beef. ${ }^{29}$ The Brazilian diet was analyzed in a population-level study by Souza et al. ${ }^{30}$ About half of Brazilian women (51.6\%) consumed beef and $27.4 \%$ consumed poultry. Although fish contains the greatest source of taurine, it is not a commonly consumed product in this population, particularly by women who live in this region. Therefore, even though Brazilian women obtain taurine from their diet, they most likely do not consume adequate amounts of this AA suggesting that supplementation may be suggested, particularly among dyslipidemic individuals.

Data from this study is important for clarifying the effects of both concurrent training in isolation and in association with taurine supplementation as it relates to the body composition and metabolic profiles of women after menopause. However, it is necessary to mention, as a limitation, such as small sample size, the lack of control for time since menopause and the amount of taurine ingested from the diet indicating that caution is needed when generalizing the conclusions found here. However, the results from this study are promising and indicate that taurine and exercise are effective at lowering lipids. Furthermore, due to the limited number of large clinical trials examining taurine as a preventive agent for dyslipidemia, more studies need to be developed before recommendations for supplementation with Taurine should be made.

\section{CONCLUSION}

In summary, there is no additional effect of taurine supplementation with concurrent training on the body composition of postmenopausal women after eight weeks of intervention. However, the combination of this AA with concurrent training helped to reduce TC and LDL-C in this population.

\section{ACKNOWLEDGEMENTS}

Coordenação de Aperfeiçoamento de Pessoal de Nível Superior (CAPES)

All authors declare no potential conflict of interest related to this article

AUTHORS' CONTRIBUTIONS: Each author made significant individual contributions to this manuscript. CB (0000-0001-9717-0433)*, FER (0000-0002-0594-2529)*, TAD (0000-00022655-9588)*, ACF (0000-0003-3302-663X), JV (0000-0003-0282-8920)*, and MRP (0000-0002-7602-3191)* conducted the interventions, assisted in the data collection, tabulation and interpretation. RAF (0000-0003-1576-8090)* and IFFJ (0000-0002-5071-0428)* made the necessary adjustments to the text and discussed the research. ${ }^{*}$ ORCID (Open Researcher and Contributor ID). 


\section{REFERENCES}

1. WHO. Research on the Menopause in the 1990's. Proceedings of a meeting. Geneva, Switzerland, 14-17 June 1994. Maturitas. 1996;23(2):109-259.

2. Abdulnour J, Doucet E, Brochu M, Lavoie JM, Strychar I, Rabasa-Lhoret R, et al. The effect of the menopausal transition on body composition and cardiometabolic risk factors: a Montreal-Ottawa New Emerging Team group study. Menopause. 2012;19(7):760-7.

3. Ramezani Tehrani F, Behboudi-Gandevani S, Ghanbarian A, Azizi F. Effect of menopause on cardiovascular disease and its risk factors: a 9-year follow-up study. Climacteric. 2014;17(2):164-72.

4. Rossi FE, Buonani C, Viezel J, Gerosa-Neto J, Mota J, Fernandes R, et al. [Effects of concurrent training on body composition and resting metabolic rate in postmenopausal women]. RPCD. 2013;13(1):12-22

5. Panissa VLG, Bertuzzi RCM, Lira FS, Júlio UF, Franchini E. Concurrent exercise: Analysis of the acute effect of the performance order on the total energy expenditure. Rev Bras Med Esporte. 2009;15(2):127-31.

6. Monteiro PA, Antunes BMM, Silveira LS, Fernandes R, Freitas Jr I. [Effect of a concurrent training on risk factors for the accumulation of hepatic fat of obese adolescents]. Medicina (Ribeirão Preto). 2013;46(1):17-23.

7. Szymanski K, Winiarska K. [Taurine and its potential therapeutic application]. Postepy hig medcyny dosw (Online). 2008;62:75-86

8. Harada H, Tsujino T, Watari Y, Nonaka H, Emoto N, Yokoyama M. Oral taurine supplementation prevents fructose-induced hypertension in rats. Heart vessels. 2004;19(3):132-6.

9. Hamilton EJ, Berg HM, Easton CJ, Bakker AJ. The effect of taurine depletion on the contractile properties and fatigue in fast-twitch skeletal muscle of the mouse. Amino acids. 2006;31(3):273-8.

10. Balducci S, Zanuso S, Nicolucci A, Fernando F, Cavallo S, Cardelli P, et al. Anti-inflammatory effect of exercise training in subjects with type 2 diabetes and the metabolic syndrome is dependent on exercise modalities and independent of weight loss. NMCD. 2010;20(8):608-17.

11. Brochu M, Malita MF, Messier V, Doucet E, Strychar I, Lavoie JM, et al. Resistance training does no contribute to improving the metabolic profile after a 6-month weight loss program in overweight and obese postmenopausal women. J Clin Endocrinol Metab. 2009;94(9):3226-33.

12. Wakayoshi K, Yoshida T, Udo M, Harada T, Moritani T, Mutoh Y, et al. Does critical swimming velocity represent exercise intensity at maximal lactate steady state? Eur J Appl Physiol Occup Physiol. 1993;66(1):90-5.

13. Silva CMd, Gurjão ALD, Ferreira L, Gobbi LTB, Gobbi S. [Effect of resistance training, prescribed by zone of maximum repetitions, on the muscular strenght, and body composition in older women]. Rev Bras Cineantropom Desempenho Hum. 2006;8(4):39-45.

14. Thompson FE, Byers T. Dietary assessment resource manual. J Nutr. $1994 ; 124(11$ Suppl):2245S-317S

15. Rutherford JA, Spriet LL, StellingwerffT. The effect of acute taurine ingestion on endurance performance and metabolism in well-trained cyclists. Int J Sport Nutr Exerc Metab. 2010;20(4):322-9.
16. Goodman CA, Horvath D, Stathis C, Mori T, Croft K, Murphy RM, et al. Taurine supplementation increases skeletal muscle force production and protects muscle function during and after high-frequency in vitro stimulation. J Appl physiol. 2009;107(1):144-54.

17. Beyranvand MR, Khalafi MK, Roshan VD, Choobineh S, Parsa SA, Piranfar MA. Effect of taurine supplementation on exercise capacity of patients with heart failure. J cardiol. 2011;57(3):333-7.

18. Alford C, Cox H, Wescott R. The effects of red bull energy drink on human performance and mood Amino acids. 2001;21(2):139-50

19. Lixandrão ME, Bonganha V, Conceição MS, Libardi CA, Berton RPdB, Cavaglieri CR, et al. [Effect of concurrent training on muscle hypertrophy and strength of postmenopausal women]. Rev Bras Ativ Fís Saúde. 2013;17(4):247-51.

20. Rossato M, Binotto MA, Roth MA, Temp H, Carpes FP, Alonso JL, et al. [Effects of a combined training of strength and endurance on body components of women on perimenopause stage]. Rev port ciênc desporto. 2007;7(1):92-9.

21. Kuller LH, Meilahn EN, Cauley JA, Gutai JP, Matthews KA. Epidemiologic studies of menopause: changes in risk factors and disease. Exp Gerontol. 1994;29(3-4):495-509.

22. Kilim SR, Chandala SR. A comparative study of lipid profile and oestradiol in pre-and post-menopausal women. JCDR. 2013;7(8):1596.

23. Venkatesan N, Rao PV, Arumugam V. Inhibitory Effect of Taurine on Puromycin Aminonucleoside-Induced Hyperlipidemia in Rats. J Clin Biochem Nutr. 1993;15(3):203-10.

24. Sjovall J. Fifty years with bile acids and steroids in health and disease. Lipids. 2004;39(8):703-22.

25. Brown MS, Goldstein JL. A receptor-mediated pathway for cholesterol homeostasis. Science 1986;232(4746):34-47

26. Oudit GY, Trivieri MG, Khaper N, Husain T, Wilson GJ, Liu P, et al. Taurine supplementation reduces oxidative stress and improves cardiovascular function in an iron-overload murine model. Circulation. 2004;109(15):1877-85.

27. Shaw I, Shaw BS, Brown GA, Cilliers JF. Concurrent resistance and aerobic training as protection against heart disease. Cardiovasc J Afr. 2010;21(4):196-9.

28. eo DI, So WY, Ha S, Yoo EJ, Kim D, Singh H, et al. Effects of 12 weeks of combined exercise training on visfatin and metabolic syndrome factors in obese middle-aged women. J Sport Sci Med. 2011;10(1):222-6.

29. Williams P. Nutritional composition of red meat. Nutr Diet. 2007;64(s4):S113-9.

30. Souza AM, Pereira RA, Yokoo EM, Levy RB, Sichieri R. Most consumed foods in Brazil: National Dietary Survey 2008-2009. Rev Saúde Pública. 2013;47(1 Supl):190S-9S. 